\title{
TINJAUAN KOGNISI DESAIN PRODUK KEMASAN SEBAGAI UNSUR IDENTITAS BUDAYA POPULER ATAS PRODUK KEMASAN MAKANAN INDUSTRI KECIL MENENGAH (IKM)
}

\author{
Moch. Junaidi Hidayat \\ Staf Pengajar Jurusan Desain Produk-Institu t Teknologi Adhi Tama Surabaya \\ Emal : junaidi.hidayat09@gmail.com
}

\begin{abstract}
Packaging is a media for producers and customers to communicate, and as such it must be capable of conveying a message through informative communication. The problem of packaging's design occurs in the conveyance of this message in the form of signs, which can be considered a game of cognition aspects. The symbolic expressions in packaging are not only visual (text, image, color and other graphic aspects) but may also be material and even functional, until packaging can be considered a symbolization of cultural development through packaging design.

This paper is the result of preliminary research result which attempted to identify, describe and prove the phenomena of customers' relationships with packaging design, namely the cognitive response to design and its effect on packaging production by Medium to Small Scale Industries (IKM). At the same time, the conceptual idea is to improve the design object of food packaging from IKMs in East Java through Media-Cultural Study. The position of IKMs becomes interesting because of the typically unique characteristics of the production/consumption process of IKMs, as compared to the factory-scale which is the market leader for packaging.
\end{abstract}

Keywords: Packaging Design, Cognition, Popular Culture

\begin{abstract}
ABSTRAK
Kemasan (packaging) merupakan media komunikasi produsen dan konsumen, sehingga harus mampu menyampaikan pesan lewat komunikasi informatif, seperti halnya komunikasi penjual dengan pembeli. Permasalahan desain kemasan terjadi ketika penyampaian pesan berupa tanda simbolik (sign) yang sesungguhnya merupakan permainan aspek kognisi. Ekspresi simbolik kemasan, tidak hanya visual ( teks, image, warna, dan aspek grafis lain) tetapi juga bentuk, material, hingga fungsi kemasan menjadi simbolisasi perkembangan budaya desain kemasan tersebut.

Makalah ini merupakan hasil penelitian awal yang mencoba mengidentifikasi, mendiskripsikan, dan membuktikan fenomena relasi desain antara pengkonsumsi (konsumen) dengan produk kemasan, yakni respon kognisi objek kemasan serta pengaruhnya terhadap produksi kemasan oleh IKM. Sekaligus sebagai gagasan konspetual mengangkat objek desain kemasan makanan Industri Kecil Menengah (IKM) di Jawa Timur dalam tinjauan Kajian Budaya-Media. Posisi IKM menajdi menarik karena pada tataran IKM proses produksi-konsumsi memiliki nilai kekhasan dibanding skala pabrikasi yang menjadi penguasa kemasan di pasar.
\end{abstract}

Kata Kunci : Desain Kemasan, Kognisi, Budaya Populer 


\section{PENGANTAR}

Daya tarik suatu produk tidak dapat terlepas dari kemasannya. Kemasan merupakan "pemicu" karena ia langsung berhadapan dengan konsumen. Oleh karena itu, kemasan harus dapat mempengaruhi konsumen untuk memberikan respon positif, dalam membeli produk. Tujuan akhir dari pengemasan adalah untuk menciptakan penjualan (Wirya-Iwan, 1999:ix). Mengamati produk-produk Industri Kecil Menengah (IKM) terutama produk makanan saat ini di pasaran memang jauh lebih bervariatif dengan kompetisi yang sangat tinggi. Salah satu usaha yang dapat ditempuh untuk menghadapi persaingan perdagangan yang semakin tajam adalah melalui desain kemasan.

Kemasan seringkali disebut sebagai "the silent sales-man/girl" karena mewakili ketidakhadiran pelayan dalam menunjukkan kualitas produk. Untuk itu, kemasan harus mampu menyampaikan pesan lewat komunikasi informatif, seperti halnya komunikasi antara penjual dengan pembeli. Bahkan, para pakar pemasaran menyebut desain kemasan sebagai pesona produk (the product charm), sebab kemasan memang berada di tingkat akhir suatu proses alur produksi yang tidak saja untuk memikat mata (eye-cathing) tetapi juga untuk memikat pemakaian (usage attractiveness).

Permasalahan desain kemasan tidak hanya sampai di sini melainkan ada pesan (sign) yang terkandung dalam kemasan bahwa konsumen diharapkan mampu setia membeli produk yang ada di dalam kemasan itu sendiri. Tulisan ini mencoba mengurai dan memberikan pemaparan sejauh mana kemasan mampu mewadahi sebuah pesan terakhir produsen (the last adv seen), penentu keputusan konsumen, sebuah brand identity dari sebuah produk. Berdasarkan UU No. 7 Tahun 1996 tentang Pangan, Kemasan didefinisikan sebagai bahan yang digunakan untuk mewadahi dan atau membungkus pangan, baik bersentuhan langsung dengan pangan maupun tidak.

Kemasan juga bisa didefinisikan sebagai seluruh kegiatan merancang dan memproduksi wadah atau bungkus atau kemasan suatu produk. Kemasan meliputi tiga hal, yaitu merek, kemasan itu sendiri, dan label. Ada tiga alasan utama untuk melakukan pembungkusan sebagai berikut:

1. Kemasan memenuhi syarat keamanan dan kemanfaatan. Kemasan melindungi produk dalam perjalanannya dari produsen ke konsumen. Produkproduk yang dikemas biasanya lebih bersih, menarik, dan tahan terhadap kerusakan yang disebabkan oleh cuaca.

2. Kemasan dapat melaksanakan program pemasaran. Melalui kemasan identifikasi produk menjadi lebih efektif dan dengan sendirinya mencegah pertukaran oleh produk pesaing. Kemasan merupakan satu-satunya cara perusahaan membedakan produknya.

3. Kemasan merupakan suatu cara untuk menghubungkan produsen dengan konsumen (aspek komunikasi termasuk di dalamnya meningkatkan laba perusahaan).Oleh karena itu, perusahaan harus membuat kemasan semenarik mungkin. Dengan kemasan yang sangat menarik diharapkan dapat memikat dan menarik perhatian konsumen. Selain itu, kemasan juga dapat mangurangi kemungkinan kerusakan barang dan kemudahan dalam pengiriman (Junaidi, 2009).

Sejarah kemasan (packaging) sesungguhnya telah dikenal sejak zaman prasejarah yaitu sejak manusia purba. Orang primitif menggunakan kulit binatang dan keranjang rumput untuk mewadahi buahbuahan yang dipungut dari hutan. Kemudian 8.000 tahun yang lalu, bangsa Cina membuat aneka ragam keramik untuk mewadahi benda padat ataupun cair. Sedangkan di Indonesia, orang membuat wadah dari bambu untuk menyimpan benda cair. Pada masa pertengahan material kemasan-pun mulai mengalami perkembangan yakni dari bahan dari kulit, kain, kayu, batu, keramik, dan kaca. Akan tetapi, pada zaman itu kemasan masih terkesan seadanya dan 
lebih berfungsi untuk melindungi barang terhadap pengaruh cuaca atau proses alam lainnya yang dapat merusak barang. Selain itu, kemasan juga berfungsi sebagai wadah agar barang mudah dibawa selama dalam perjalanan.

Peranan kemasan sebenarnya baru dirasakan pada sekitar tahun 1950-an, saat banyak munculnya supermarket atau pasar swalayan. Kemasan harus "dapat menjual" produk-produk di rak-rak toko. Pada saat itupun kemasan hanya berfungsi memberikan informasi atau memberitahukan informasi kepada konsumen tentang apa isi atau kandungan di dalam kemasan tersebut. Tahun 1980-an, persaingan dalam dunia usaha semakin tajam dan kalangan produsen saling berlomba untuk merebut perhatian calon konsumen, bentuk, dan model kemasan dirasakan sangat penting peranannya dalam strategi pemasaran. Di sini kemasan harus mampu menarik perhatian, menggambarkan keistimewaan produk, dan "membujuk" konsumen. Pada saat inilah kemasan mengambil alih tugas penjualan pada saat jual beli terjadi. Banyak yang sudah menampilkan kaidah kemasan, tidak terbatas pada kemasan sebagai pembungkus dan pelindung produk saja, tapi sudah disertai dengan keindahan kemasannya (Cenadi-Suharto, Jurnal Nirmana Vol. 2 - No. 1, Januari 2000: 94). Hermawan Kartajaya, seorang pakar di bidang pemasaran mengatakan bahwa teknologi telah membuat packaging (kemasan) berubah fungsi, dulu orang bilang "Packaging protects what it sells (Kemasan melindungi apa yang dijual). "Sekarang, "Packaging sells what it protects (Kemasan menjual apa yang dilindungi)". Dengan kata lain, kemasan bukan lagi sebagai pelindung atau wadah, tetapi harus dapat menjual produk yang dikemasnya (Kertajaya, 1996:263).

Aspek kognisi merupakan area 'permainan' yang sedang dimainkan oleh fungsi kemasan itu. Dari sisi produsen terus memproduksi simbolisasi (sign) agar kemasan bisa menarik perhatian konsumen lalu tanpa sadar maupun dengan kesadaran, konsumen membeli produk. Sementara konsumen terus menerus menerima dan merespon tanda (sign) yang diciptakan baik secara visual hingga bentuk dan material kemasan untuk 'dikonsumsi'. Sejauh mana aspek kognisi ini mampu memainkan peran dalam desain kemasan makanan Industri Kecil Menengah (IKM)?

\section{PEMBAHASAN}

Desain perlu diperhatikan pada konteks konsumerisme dikarenakan desain memainkan peranan vital di dalamnya. Desain bisa memperbaiki fungsionalitas tahan lama bagi konsumen (pendesainan ulang produk yang konstan juga bisa membuatnya lebih buruk), namun ini juga merupakan cara menciptakan perbedaan di antara berbagai barang yang secara dasar sama. Penemuan baru maupun pendesainan ulang penting bagi dinamika konsumerisme, keduanya menciptakan kebutuhan baru, hasrat baru, ketidakpuasan dengan sesuatu yang sudah ada melalui mekanisme keusangan psikologis.

Sebelum konsumsi yang terjadi orangorang harus mengetahui produk apa yang eksis dan kemana memperolehnya. Dengan kata lain, antara pelaku manufaktur dan konsumen ada wilayah distribusi, pemasaran, iklan, pesanan melalui surat, toko, dan berbelanja. Toko merupakan tempat yang signifikan dikarenakan toko adalah tempat nilai guna dipertukarkan menjadi nilai tukar, tempat berbagai barang konsumsi dipertukarkan untuk uang, yaitu menjadi nilai komoditi. Karena toko dan pertokoan saling bersaing satu sama lain, desain merupakan wahana penting untuk meningkatkan daya tariknya bagi pelanggan dan mendiferensiasi dirinya dengan pesaing melalui tampilan, desain kemasan adalah contoh nyata tersebut.

Secara tidak langsung, dunia konsumerisme menjadi sebuah dunia permainan life style yang bersifat material, imanen, dan sekuler dengan pengontrol sangat kuat berupa selera, citra, hasrat, kekuasaan, yang pada akhirnya menciptakan ruang-ruang dekontruksi dan permainan 
moral (pembanalan, chaos, cabul, vulgar, dan lainnya) tanpa batas sehingga sangat penuh dengan ketelangjangan (transparency) serta tanpa rahasia (obscene) yang pada akhirnya melahirkan budaya material (material culture) pada budaya kapitalisme global (Pilliang, 2004:325-328).

Makalah ini juga mencoba mengurai dan memberikan pemaparan sejauhmana kemasan mampu mewadahi sebuah pesan terakhir produsen (the last adv seen), penentu keputusan konsumen adalah sebuah brand identity dari sebuah produk kemasan makanan. Konsumen membelinya karena ketertarikan fisik bukan atas kesadaran apa yang terkandung dalam isi saat membelinya.

Untuk itulah perlu adanya desain secara berbeda setiap produk. Sehingga nilai guna dan tukar yang terjadi ketika dikomodifikasikan akan berubah menjadi nilai tanda yang dipertukarkan di antara produk. Di sinilah proses membaca, interpretasi, dan evaluasi terjadi. Berbagai respon emosional, estetik, dan kesenangan juga terlibat. Berbagai proses sebanding terjadi dalam kaitannya dengan barangbarangyang didesain, dimana para konsumen 'membaca' produk dan gaya desain. Mereka mengapresiasi atau membenci kualitas estetik atau formal produk dan menafsirkan berbagai pesan dan maknanya. Desain tidak hanya tentang aplikasi teknologi, bentuk, dan fungsi. Lebih dari itu, desain adalah tentang aspek manusia dan kebiasaannya (behaviour) (Slack, 2006:50).

Donald A. Norman dalam Emotional Design: Why We Love (or Hate) Everyday Things memaparkan secara lebih detail relasi antara emosi dan desain dalam 3 (tiga) tingkatan. Pertama, yang bersifat kasar (visceral), yaitu emosi yang bangkit dari penampakan luar, pandangan pertama, atau sentuhan pertama. Kedua, yang menyangkut tingkah laku (behavioural), yaitu emosi yang bangkit dari penggunaan produk yang menyangkut fungsi, kinerja (performance) dan kegunaan (usability). Ketiga bersifat reflektif, yaitu emosi yang bangkit akibat perenungan dalam jangka panjang dengan melibatkan di dalamnya berupa memori, perasaan, dan emosi (Norman, 2004:38). Aspek memori, perasaan, dan emosi adalah aspek-aspek dalam pikiran (kognisi) yang sejauh ini ada dan berada pada produk hasil desain. Dalam hal ini, kemasan makanan IKM.

Lebih jauh lagi, hubungan konsumen dengan produk dalam banyak kasus lebih aktif dibanding dengan kasus seni antara orang dengan lukisan atau patung. Sebagai ilustrasi, John Walker menggambarkan orang tidak hanya menggagumi penampilan visual mobil, mereka masuk kedalamnya, mengendarai, mencuci, dan memperbaikinya. Dengan kata lain, barang yang didesain mungkin kurang memiliki kedalaman intelektual seperti karya seni namun, siapapun bisa berpendapat bahwa keterlibatan pengguna dengannya lebih bersifat fisikal dan intim-bahkan beberapa barang didesain serta dikenakan di tubuh bahkan dikonsumsi secara langsung. Jadi, isunya bukan hanya apa yang dilakukan desain terhadap orang, tetapi apa yang orang lakukan dengan desain. Inilah suatu pertimbangan nilai pertukaran komoditi tanda yang terjadi dalam masyarakat produksi-konsumsi. Kemasan adalah contoh nyata bahwa saat ini konsumen tidak hanya membeli isi (produk terkemas), tetapi juga membeli wadah (kemasan). Artinya, secara langsung konsumen terlibat secara fisik, intim, bahkan langsung mengkonsumsi makanan yang ada di dalamnya sekaligus makanan yang terkonsumsi itu juga dibentuk (secara visual) guna kebutuhan konsumsi dan menarik perhatian.

\section{Prinsip Perbedaan Desain Kemasan}

Sesungguhnya banyak kecenderungan yang mulai bergeser bagi produsen makanan dari produk makanan sekaligus desainer kemasannya yaitu pergeseran fungsi praktis dan instrumental ke fungsi komunikatif produk. Sedang untuk nilai kekontrasan, objek yang memiliki fungsi praktis, dan instrumental tertentu khususnya pada tingkat yang tinggi (dipahami sebagai objek produk kemasan yang sangat baik-ideal) 
menjadi objek desain untuk idealisasi atau perolehan mental (mental acquisition) objek desain.

Hal ini dipahami bukan sebagai perubahan desain secara umum, tetapi merupakan paradigma tambahan yang merujuk pada kelas khusus dalam hal produk, kecenderungan industri dan maksud sosial, sehingga dihasilkan produk dengan bentuk yang lebih ekspresif. Prinsip perbedaan (different) ini banyak digunakan oleh produsen makanan serta desainer produk, guna menyampaikan pesan terhadap objek desain dan produk yang dibuat serta diproduksinya, sehingga pasar bisa dengan mudah mengenal, mengerti, tertarik, dan selanjutnya tentu saja selanjutnya menjadi 'konsumtif' dengan membeli produk tersebut.

Prinsip perbedaan khususnya oleh desainer bergerak pada kisaran 'formatif vs reproduktif'. Meski demikian, ada 2 (dua) kecenderungan dalam proses mendesain yakni kecenderungan yang tidak disadari (terhadap berbagai komponen ekspresi dan makna yang dapat dikendalikan) dan kecenderungan yang disadari (terhadap komponen ekspresi dan makna yang dapat digambarkan).

Pada desain 'formatif" mengacu fungsi instrumental, operational, dan praktis serta tergantung kepada inovasi dalam struktur teknis dan operasional, sedangkan desain 'reproduktif' tematik dapat berlangsung lewat aliensi (antara kontradiktif fungsi instrumen dan komunikatif akan jauh lebih besar). Dalam hal ini, tampilan kemasan produk makanan harus memiliki tampilan yang khas karena saat ini kecenderungan masyarakat konsumsi dengan perkembangan yang lebih evolusioner dalam budaya populer terus mengambil tempat khususnya pangsa pasar dalam negeri. Dengan kata lain, desain kemasan harus berani bersaing dengan hasil pabrikasi. Dalam istilah pemasaran bahwa "isi memang penting tetapi saat ini wadah jauh lebih penting".

Konsep wadah lebih penting dibanding isi ini juga menjadi hal yang penting dalam prinsip desain kemasan. Keinginan produsen yang selalu ber'cita-cita' menyaingi produk pabrikasi sesungguhnya merupakan sebuah bentuk kapitalisme industrialisasi saat ini. Tidak hanya produsen besar sengaja membutakan konsumen dengan sajian yang menarik, tetapi sesungguhnya tidak dibutuhkan olehnya, yang secara tidak langsung pemain kecil (seperti: Industri Kecil Menengah -IKM) harus mengikuti perkembangan budaya populer yang ditiupkan oleh produsen kelas kakap ini. Konsep "wadah lebih penting" sepertinya sudah mulai menjejali masyarakat tingkatan produsen skala kecil menengah saat ini.

Penulis melihat dalam masyarakat konsumtif saat ini sesungguhnya sudah mementingkan 'wadah' dibanding 'isi'. Tidak saja dalam studi kasus kemasan keripik buah saja, tetapi pada tingkatan konsumtif lain, misal ketika ada di swalayan atau supermarket, banyak orang tidak ubahnya membeli 'kucing dalam karung' dengan membeli kemasan yang sangat menggoda, tetapi tidak mengerti isi dibalik kemasan itu. Ini merupakan ciri khas cultural industry yang mewabah saat ini bahwa masyarakat mengeluarkan uangnya untuk 'wadah' bukan 'isi'. Sebuah ciri khas dilematik masyarakat konsumsi.

Baudrillard berpendapat bahwa konsumsi bukan sekedar nafsu untuk membeli begitu banyak komoditas, satu fungsi kenikmatan, satu fungsi individual, pembebasan kebutuhan, pemuasan diri, kekayaan, atau konsumsi objek. Konsumsi berada dalam satu tatanan pemaknaan pada satu objek, satu sistem, atau kode tanda, satu tatanan manipulasi tanda, manipulasi objek sebagai tanda, satu sistem komunikasi (seperti bahasa), satu sistem pertukaran (seperti kekerabatan primitif), satu moralitas, yaitu sistem pertukaran ideologis, produksi perbedaan, menciptakan isolasi dan mengindividu, satu pengekang orang secara bawah sadar, baik dari sistem tanda sosio-ekonomi-politik, dan satu logika sosial (Boudrillard, 2009: xxxiv).

$$
\text { Masyarakat konsumsi adalah }
$$
masyarakat yang dibentuk dan dihidupi 
oleh konsumsi, yang menjadikan konsumsi sebagai pusat aktivitas kehidupan dengan hasrat selalu dan selalu mengkonsumsi. Dalam masyarakat konsumsi pandangan bahwa barang (komoditi) tidak lebih dari sekedar kebutuhan yang memiliki nilai tukar dan nilai guna kini pelan-pelan mulai ditinggalkan dan diganti dari komoditas menjadi tanda dalam pengertian Saussurian.

Dengan demikian konsumsi, tidak dapat dipahami sebagai konsumsi nilai guna, tetapi terutama sebagai konsumsi tanda. Dalam masyarakat konsumen hubungan menusia ditransformasikan dalam hubungan objek yang dikontrol oleh kode. Objek adalah tanda. Perbedaan status dimaknai sebagai perbedaan konsumsi tanda, sehingga kekayaan diukur dari banyaknya tanda yang dikonsumsi. Mengkonsumsi objek tertentu menandakan kita berbeda atau dianggap sama dengan kelompok sosial tertentu, jadi kode mengambil fungsi kontrol terhadap individu. Pandangan Baudrillard dalam bukunya 'Masyarakat Konsumsi' lebih jauh mengurai, proses konsumsi dapat dianalisis dalam perspektif dua aspek yang mendasar yaitu: pertama, sebagai proses signifikansi dan komunikasi, yang didasarkan pada peraturan (kode) dan praktik-praktik konsumsi masuk dan mengambil maknanya. Di sini konsumsi merupakan sistem pertukaran, dan sepadan dengan bahasa. Kedua, sebagai proses klasifiaksi dan diferensiasi sosial, kali ini objek-objek / tanda-tanda ditahbiskan bukan hanya sebagai perbedaan yang signifikan dalam satu kode, tetapi sebagai nilai yang sesuai (aturan) dalam sebuah hirarki.

Sementara itu sosiolog dari Prancis, Pierre Bourdieu, menghubungkan konsumsi dengan simbol-simbol sosial dalam masyarakat. Dalam pandangannya produk konsumsi merupakan simbol status dan kelas sosial seseorang. Musik klasik misalnya, hanya dinikmati orangorang tertentu (biasanya dari kelas atas). Konsumsi dibentuk oleh ide, simbol, selera, yang kemudian secara tidak langsung maupun tidak menciptakan pembedaan dalam masyarakat. Dalam konsumsi, selera, preferensi, gaya hidup, dan standar nilai ditentukan oleh kelas yang lebih superior. Kelas atas bukan hanya unggul secara ekonomi politik, namun juga budaya dengan menentukan dan melakukan hegemoni dalam pola-pola konsumsi. Ini menandakan prinsip perbedaan dalam kelas yang diikuti prinsip perbedaan mengkonsumsi atas produk.

Ketika produksi kapitalisme mencapai puncak kelimpahan barang, sehingga kebutuhan tercukupi, perusahaan berusaha bukan hanya mencipta barang, namun sekaligus menciptakan kebutuhan. Ini merupakan upaya kapitalisme pasar untuk terus menguasai kehidupan. Berbagai instrumendancara-carapersuasif,kapitalisme memaksa masyarakat mengkonsumsi tanpa henti. Muncul kemudian kebutuhan semu, bukan karena butuh (need), tetapi lebih pada ingin (want). Produksi tentu tak lepas dari konsumsi, pasangannya. Sebab keduanya saling membutuhkan. Pada awal perkembangan masyarakat, produksi adalah upaya usaha memenuhi kebutuhan sendiri. Akan tetapi, barang yang dihasilkan berlebih, maka ditukarkan barang lain, untuk tujuan yang berbeda. Pertukaran barang ini kemudian memunculkan pasar, dan barang tersebut berubah nilainya menjadi komoditas. Karl Marx melihat hal tersebut sebagai perubahan nilai guna (use value) menjadi nilai tukar (exchange value). Di sini konsumsi dapat menjadi objek pembahasan strategis yang menentukan kekuatan, khususnya dalam distribusi nilai yang sesuai aturan (melebihi hubungannya dengan pertanda sosial lainnya: pengetahuan, kekuasaan, budaya, dan lain-lain (Boudrillard, 2009:91).

Diakui produsen (berdasar penelitian awal yang dilakukan penulis melalui wawancara dengan salah satu pemilik IKM keripik buah di Batu, Malang-Jawa Timur) bahwa dengan merubah kemasan menjadi lebih menarik dengan visual dan struktur (material dan bentuk) yang lebih 'estetis' secara tidak langsung ikut menambah jumlah produksi semakin besar yang berindikasi terhadap laba bersih perusahaan. 
"Prinsip differensiasi kita gunakan dalam mendesain, tetapi IKM harus mampu tampil beda. Terbukti, meski tidak tahu rasa tetapi konsumen lebih tertarik ketika ditawari dengan kemasan yang menggoda," ujar Rony, pemilik IKM keripik Buah merek Nature di Batu-Malang.

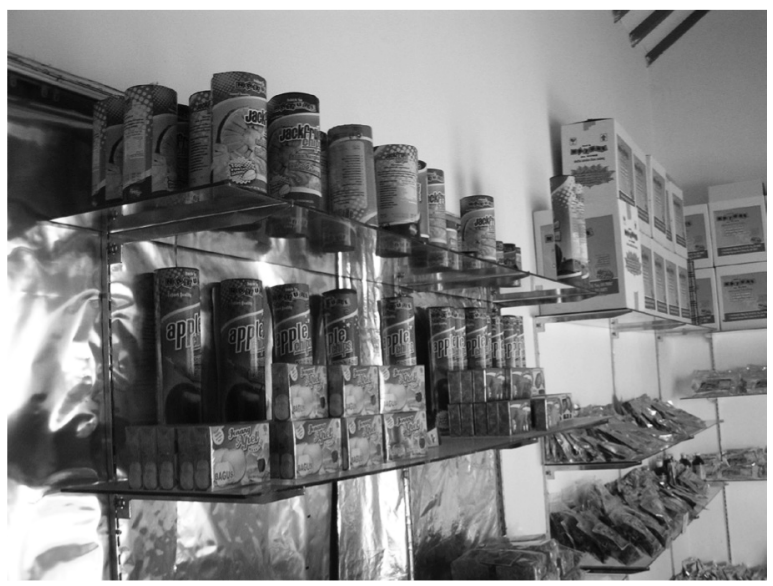

Gambar 1: Kemasan Karton Keripik Buah Nature (Sumber : koleksi penulis, 21 Desember 2009)

Di sini terlihat bahwa 'evolusi budaya' kemasan IKM yang dahulu dianggap buruk, tidak eye-catching, atau tidak menjual dan kini sudah sangat berubah dengan pemahaman pentingnya menjual wadah. Prinsip different selalu digunakan untuk menempatkan produk keripiknya memiliki strenght point dibanding produk yang lain sekaligus menciptakan masyarakat konsumen (consumer society) menjadi budaya konsumen (consumer culture), khususnya bagi target pasar IKM ini. Ada nilai kreativitas yang berkembang dan berbeda pada tingkatan Industri kecil-menengah ini.

Sesungguhnya hakikat dari kreativitas adalah kekayaan intelektual, IKM dapat bertahan karena memiliki ciri khas yang tidak dimiliki oleh pengusaha besar (pabrikasi). Begitu pula dengan aspek produksi, sesungguhnya sifat dasar industri kreatif adalah value bagi konsumen, maka sifat industri ini tidak bisa menggunakan pola produksi massal melainkan customization karena sifatnya yang unik. Mungkin sejauh ini, produk IKM memang sangat fokus dibanding dengan pabrikasi, tetapi dalam tingkat persaingan pasar tentu saja pengusaha besar cenderung lebih berkuasa karena motivasi mereka adalah profit yang berbanding terbalik dengan kondisi sektor hilir yaitu IKM.

Penulis melihat pemahaman geneologi kreativitas sesungguhnya berbasis pada komunitas. Artinya pada tingkat komunitas inilah gerakan kreatif itu muncul dengan sempurna yang selalu berkembang, beradaptasi, dan menciptakan hal baru. Kelompok 'subkulture' inilah yang bisa jadi mesin penggerak indutri kreatif di Indonesia. Hasilkreativitas, dalam hal ini desainkemasan makanan IKM selalu bisa beradaptasi dengan konsumen yang mereka tuju. Yang tanpa disadari membentuk fenomena tersendiri baik dikalangan produsen (IKM) maupun pengenalan oleh konsumen. Kemampuan IKM ini telah membentuk kultur budaya populer baru, tidak hanya kemasan produk makanan IKM, tetapi sekaligus nilai material, mode kerja, hingga value desain. Namun, di sisi lain serbuan dari kapitalisme pengusaha besar menjadi penghambat ekonomi kreatif sekaligus dilematik bagi pengembangan desain ditingkat IKM makanan. Untuk itu, perlu kebijakan yang sangat tegas dari pelaku industri kreatif itu sendiri serta sinergi antara industri, pemerintah, maupun komunitas sekaligus masyarakat terkait.

\section{Politik Identitas Kemasan}

Pada dasarnya, kemasan juga dapat dipahami sebagai sebuah kompetisi dari sebuah produk, kompetisi ini akan mendorong kebutuhan untuk diferensiasi pasar dan kebutuhan untuk selalu berbeda dari pasaran. Di sinilah fungsi identitas dari kemasan yakni berfungsi sebagai alat komunikasi perbedaan produk secara visual. Secara penampilan, bisa dipahami bahwa tanpa kehadiran desain kemasan yang berbeda, maka semua merek produk pada hakikatnya sama. Orang akan sulit membedakan antara roti, sayur, hingga parfum, lipstik bahkan minuman keras karena semua akan tampak sama.

Di sinilah lalu ditangkap oleh sebuah proses identifikasi bahwa karakteristik yang 
membedakan produk sangat diperlukan dan juga diperlukan kekontrasan produk. Idealnya, ketika desain kemasan mampu memberikan informasi yang jelas dan spesifik kepada konsumen (baik langsung maupun tidak langsung) dan dengan tujuan utama untuk mengalahkan kompetitor, menghindari kebingungan konsumen, dan mempengaruhi konsumen untuk membeli sehingga desain kemasan menjadi faktor penting dalam keberhasilan rencana pemasaran merek perusahaan terintegrasi (Klimchuck, 2006:36).

Politik identitas kemasan ini sangat penting khususnya bagi pemasaran perusahaan. Di sini dipahami bahwa memenangkan sebuah pertandingan adalah tidak ubahnya sama dengan mengarahkan pada prinsip perubahan kepada kebutuhan ekonomi (economy capital) yang secara utuh juga dipahami sebagai sebuah pergeseran nilai sosial budaya. Konsumen diarahkan untk terus mengkonsumsi oleh produsen melalui bahasa visual dan desain konstruksi kemasannya. Pertimbangan lain bagi perusahaan adalah memenangkan kompetisi melalui struktur masyarakat konsumsi tertentu (segmentasi) dengan melihat basis konsumen mana yang paling dapat memanfaatkan produk tersebut atau siapa yang dapat menjangkau dan menerima produk. Hal ini dijadikan pertimbangan sebagai tools untuk mengarahkan desain kemasan lalu membuatnya dalam iklan untuk menarik kelompok konsumen tertentu. Dalam arena kompetisi ini, desain kemasan tidak hanya dituntut menarik secara visual saja, tetapi mampu merangsang minat dan kesadaran, dan mempengaruhi keputusan pembelian konsumen dalam sekejap. Meskipun keputusan untuk membeli adalah sebuah keputusan atas kebutuhan emosional yang semu dan mungkin palsu (emotional and false needs). Inilah yang menjadikan kemasan dan iklan produk tidak hanya berbeda dari warna, gaya tipografi, huruf, struktur dan elemen desain saja, tetapi juga perlu memasukkan politik identitas (baca: indikasi kategori berdasar segmentasi tertentu) bagi kebutuhan konsumen.
Pada dasarnya iklan juga dipahami sebagai produk kebudayaan massa, sebuah produk kebudayaan masyarakat industri yang ditandai oleh produksi dan konsumsi massal. Kepraktisan dan pemuasan jangka pendek antara lain merupakan nilai kebudaaan massa (Jefkins, 1996:27). Artinya, massa dipandang tidak lebih sebagai konsumen. Hubungan antara produsen dan konsumen adalah hubungan komersial semata dimana interaksi yang terjadi tidak memiliki fungsi lain, selain memanipulasi kesadaran, selera dengan keputusan bawah sadar, dan perilaku konsumsi yang tinggi. Aspek kognisi sekali lagi memainkan peranan penting dalam membentuk value yang dipertukarkan baik materiil melalui fisik desain kemasan maupun immateriil melalui pemahaman, memori produk, pengenalan produk, hingga tanda (sign) yang mudah diingat (struktur memori) bagi konsumen.

Pada titik akhir, desain kemasan adalah sebuah bisnis kreatif yang mengkaitkan bentuk, struktur, material, warna, citra, tipografi, danelemendesaindenganinformasi produk agar dapat dipasarkan. Desain kemasan juga berlaku sebagai pemasaran produk dengan mengkomunikasikan kepribadian atau fungsi produk konsumsi yang unik mampu membius konsumen.

\section{Antara Persepsi, Resepsi, dan Selera (Ranah Kognitif)}

Kognisi adalah bagaimana cara berpikir manusia (Sternberg, 2008:2). Sedangkan dalam pemahaman psikologi kognitif diartikan bahwa suatu bidang studi tentang bagaimana manusia memahami, belajar, mengingat, dan berpikir tentang suatu informasi. Dalam hal ini, penulis melihat desain kemasan adalah area konsumerime. Tidak banyak penulis temui secara teks komprehensif yang mengolah desain dan konsumerisme karena mungkin meneliti subjek ini perlu merujuk pada cakupan literatur yang sangat luas dan beraneka ragam 'pisau bedah' mulai dari politik ekonomi berkaitan dengan komoditi dan relasinya dengan kebutuhan manusia, sejarah budaya 
dengan ekonomi masyarakat, hak konsumen, studi media massa, gaya hidup, organisasi konsumen, masyarakat sebagai penikmat, dan tentu faktor desain itu sendiri.

Desain (kemasan), perlu meletakkan perhatian besar pada konsumerisme karena desain memainkan peranan vital. Sebuah penemuan baru maupun re-design penting bagi dinamika konsumerisme karena bisa menciptakan kebutuhan baru, hasrat baru, ketidakpuasan dengan sesuatu yang sudah ada melalui keusangan psikologis. Kata resepsi sengaja penulis angkat karena resepsi berbeda dengan dampak (dalam bingkai desain produk kemasan).

Resepsi menggambarkan fase awal asimilasi, sementara dampak merujuk kepada efek-efek yang mengikutinya. Teori resepsi menantang otonomi teks, dan secara implikasinya adalah barang-barang yang didesain, dengan berpendapat bahwa interpretasi dan evaluasi ditentukan bukan hanya oleh sifat dasar teks dan barang itu sendiri, tetapi juga oleh karakter sang penerima atau konsumen. Dimana dalam konstruksi pemahaman Marx, akan diingat bahwa barang-barang akan mendapatkan 'finish-akhirnya' dalam konsumsi (Walker, 2010:196).

Resepsi diartikan bahwa di dalam desain kemasan berkaitan dengan konsumerisme terdapat respon emosional, estetik, dan kesenangan sekaligus. Para konsemen harus mampu 'membaca' produk dan gaya desain, mengekspresikan, mengapresiasi hingga membenci produk, menafsirkan pesan, dan makna sekaligus. Dengan kata lain, sesungguhnya konsumen memiliki hubungan yang lebih aktif dibandingkan dengan karya seni misalnya patung dan lukisan. Sebagai gambaran, ketika membeli Bakpia-makanan khas Yogyakarta, saat ini konsumen tidak hanya disajikan sebuah kotak kemasan saja, tetapi saat mereka membeli dengan jumlah tertentu akan diberikan sebuah kemasan jinjing yang khas agar 'gaya hidup' mereka lebih terlihat eksklusif dibanding dengan menggunakan tas plastik meski baru menjangkau aspek fungsi belum estetis.

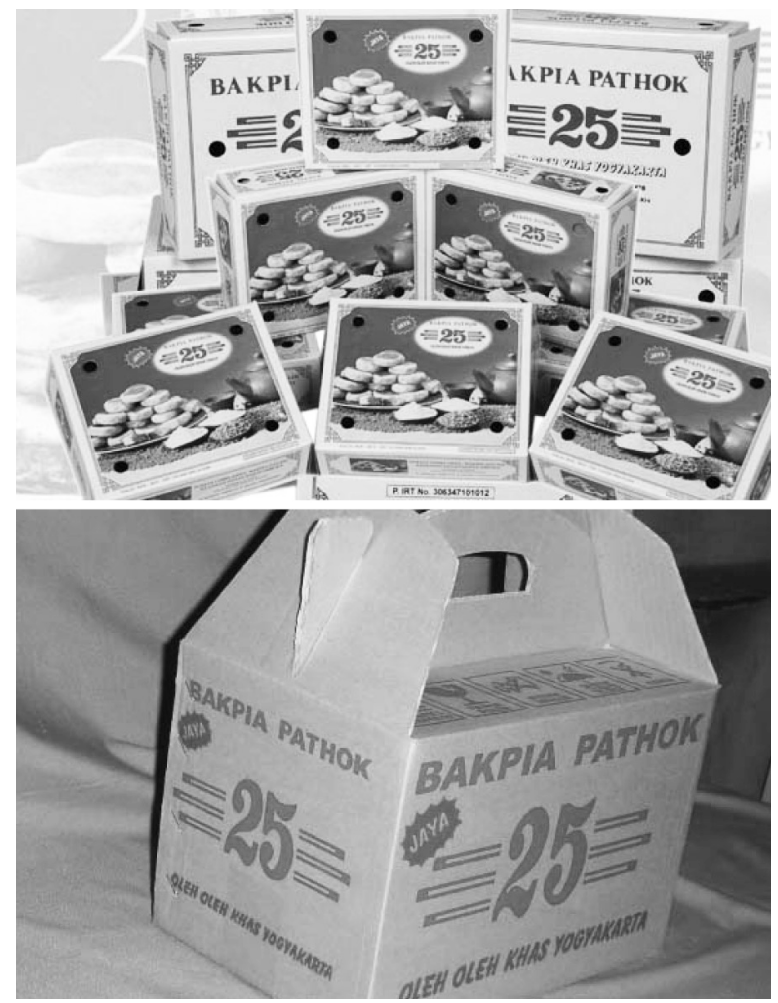

Gambar 2: Kemasan Bakpia Pathok dan wadah jinjing untuk pembeli dengan jumlah banyak (sumber: www.bakpia25.com)

Contoh lain, ketika sebuah makanan ringan sekelas keripik buah khas BatuMalang, dikemas dengan tampilan kardus atau plastik akan berbeda ketika dikemas menggunakan aluminium foil atau corragated paper dengan bentuk yang menyerupai makanan khas pabrikan sehingga konsumen tertarik. Bukan sekedar aspek fungsi, tetapi sudah menjangkau aspek gaya hidup dan estetika produk melalui tampilan visualnya (citra/image-nya).

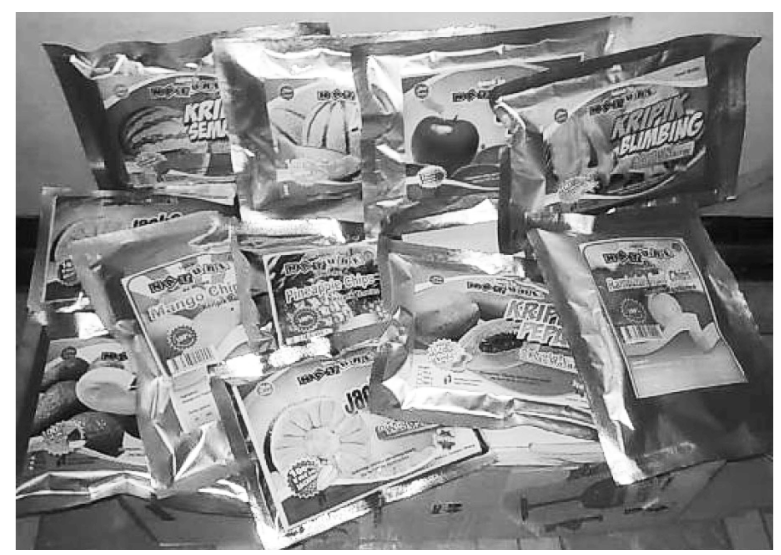




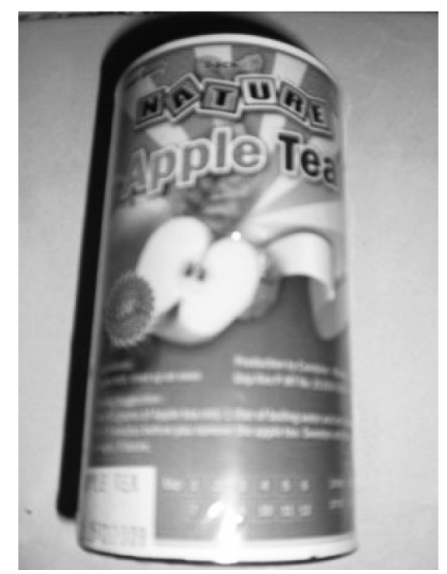

Gambar 3. Kemasan Aluminium Foil Keripik Buah Nature dan kemasan karton (corragated papper) yang lebih ekslusif ( Sumber : koleksi penulis, 21 Desember 2009)

Isu yang terjadi dalam resepsi ini sesungguhnya bukan hanya apa yang dilakukan desain terhadap konsumennya, tetapi apa yang konsumen lakukan dengan desain. Artinya ada hasrat dan kebutuhan konsumen yang dipermainkan oleh desainterlepas antara nyata atau palsu. Perasaan palsu konsumen bisa besar peluang terjadinya apalagi sudah dibungkus dengan publisitas 'iklan' yang masif dan ilusif. Sementara di sisi lain, konsumen juga memiliki kebebasan memilih produk tergantung dari tingkat status sosialnya, yang bisa diartikan bahwa hukum yang berlaku dalam masyarakat konsumen bahwa semakin kaya strata sosial konsumen, maka semakin besar kebebasan menentukan dan memilih suatu produk. Di sinilah faktor selera menjadi signifikasi dalam daya tarik desain kemasan bagi sebagian konsumen.

Meskipun selera acapkali dimanifestasikan dalam kaitan dengan benda material atau bisa diartikan pula bahwa selera juga bisa diartikan dalam pandangan konsumen dan produsen sekaligus. Selara adalah konsep yang paradoks, menimbulkan tekateki antara kesenangan atau ketidaksenangan akan produk, selera secara estetis juga dipahami sebagai kemampuan membedakan antara yang nyata dan yang palsu (false) dalam konsumsi produk, perkara suka, dan tidak suka dalam pengambilan keputusan, dan lain sebagainya. Akan tetapi, sesungguhnya selera juga paradoks untuk meruntuhkan ideologi individu tentang makna unik, personal, privat, bahkan tidak ada hubungannya dengan faktor semacam pendidikan, kelas, profesi, dan seterusnya.

Sebagai contoh, dalam pengalaman penulis saat memberikan pelatihan kemasan UKM di Jawa Timur, produsen makanan suwar-suwir (permen tape khas JemberJatim) tidak bermasalah ketika kemasan makanannya diubah, tetapi ketika warna khas makanan yang mencolok yakni komposisi waran hijau-kuning-merah, diubah justru produsen mempermasalahkannya. Hal ini dikarenakan bukan soal perubahan warna, tetapi identifikasi produk yang sudah dikenal konsumen serta perhatian atas selera konsumen bahwa warna yang asli dalam persepsi konsumen adalah hijau-kungingmerahyang di'grafis' secara vulgar. Fanatisme konsumen terhadap produk bisa didekati dengan warna mencolok yang 'haram' untuk diganti, meski desain kemasannya berubah. Artinya ada respon persepsi kemasan yang tidak ingin diubah menurut konsumen atau ada memori yang kuat dalam benak pembeli akan produk tertentu melalui representasi desain kemasannya.

Ini membuktikan bahwa desain produk kemasan yang 'baik' dalam level ini tidak bisa diartikan sebagai selera yang buruk atau kitsch. Hal ini bernilai paradoks bahwa kitsch di sini justru dinikmati oleh 2 (dua) kelompok sosial konsumen berbeda, satu sisi sebagai sebuah identifikasi produk sedangkan di sisi lain dimaknai sebagai 'kedahsyatan' produk, romantisme produk, hingga rasa menyenangkan saat membeli. Aspek kognisi (memori, persepsi, representasi) inilah yang seharusnya mendapat porsi lebih baik dari sisi produsen maupun konsumen serta desainer kemasan sebagai 'aktor intelektual' dibalik keluarnya desain kemasan. Keluarnya tanda (sign) yang dihadirkan melalui tampilan bentuk, material, serta aspek visual dalam kemasan. Hal ini berkaitan dengan kesadaran akan selera, selera merupakan pencerapan inderawi tentang kesukaan terhadap sesuatu sekaligus sebagai nilai gaya hidup tersendiri. 
Dalam perspektif sosiolog Prancis, Pierre Bordieu dalam La Distinction, memberikan perspektif bahwa keseluruhan rangkaian selera terikat erat dan tidak mungkin terpisahkan dari gaya hidup kelompok tertentu, semua selera terkorelasi dengan faktor kelas, modal ekonomi, modal simbolik (budaya), pekerjaan, dan lain sebagainya. Konsumerisme adalah seperti saluran bebas selera karena ruang-ruang yang terjadi di dalamnya di koordinasi dan dikendalikan oleh dorongan selera yang kuat. Selera adalah sebuah pondasi utama dalam konsumerisme yang dilembagakan lewat ekonomi kapitalis global. Kapitalis global merubah keinginan (want) menjadi kebutuhan (need). Artinya, kebutuhan tersebut sengaja diciptakan. Kapitalisme tidak hanya memproduksi barang-barang, akan tetapi juga memproduksi kebutuhan dan dorongan hasrat dibalik wacana libidonomics (Pilliang, 2004:329-330).

\section{Menuju Era ) RUP [ R(:ZZ XQ}

Perpektif ini terinsiprasi dari frase seorang Arsitek Amerika terkenal, Louis Sullivan dengan gerakan modern Arsitektur dengan isitilah 'form follow function' (bentuk mengikuti fungsi) (Crosby Lockwood Staples, London, 1975:13).

Dari frase inilah, penulis mencoba memasukkan kedalam konteks desain kemasan di mana kemasan selain dituntut melindungi, membungkus, mengirim, mengeluarkan, menyimpan, mengidentifikasi, juga memiliki 'beban' agar mudah dibedakan dengan produk lain ketika berada di pasaran agar dikenal dengan baik oleh konsumen. Bentuk kemasan harus fleksibel mengikuti kebutuhan produk yang menjadi objek yang dikemasinya. Istilah 'form follow fun' mungkin lebih sesuai dengan kondisi saat ini. Dimana 3 (tiga) komposisi pelaku desain kemasan yakni produsen, konsumen, dan desainer diberikan kebebasan untuk menginterpretasikan desain kemasan suatu produk. Bebas dalam banyak hal dengan tetap mengedepankan fungsi utama kemasan. 'Bentuk mengikuti kesenangan' bisa juga diartikan sebuah frasa ideologis dari kondisi sosial budaya dan ekonomi yang di interpretasikan dalam desain guna membayangkan 'yesterday's future' (dalam persepsi penulis adalah kekinian tanpa meninggalkan aspek perubahan yang terjadi sebelumnya) (Klimchuck, 2006: 121).

Dengan kata lain, frase form follow fun juga seperti halnya antara wadah dan isi, keduanya bisa dilihat sebagai sebuah tubuh yang tidak mungkin dipisahkan, di mana wadah menjadi ukuran penting bagi tubuh yang ada di dalamnya, begitu pula sebaliknya isi memiliki peranan penting bagi banyak pihak dibanding tampilan wadahnya saja.

\section{SIMPULAN}

Berdasarkan kajian di atas, dapat ditarik simpulan bahwa mengkaji desain produk kemasan (khususnya kemasan makanan yang diproduksi IKM) berkaitan dengan konsumsi memang masih belum banyak diuraikan dan jarang ditemui. Ranah berpikir konsumsi selalu disikapi dengan arena berpikir ekonomi, psikologis, dan sosiologis. Desain kemasan juga harus dipahami sebagai sebuah media informasi bagi produsen menciptakan kesadaran akan citra merek (brand image) dan kesadaran akan produk itu sendiri (brand awereness), sehingga ada pemenuhan cognitive objective (anjuran untuk membeli dibenak konsumen) yang harus diimbangi dengan behaviour objective (usaha menggiring konsumen untuk membeli). Bagi desainer dapat dipahami sebagai sebuah ranah kreativitas dan produktivitas kerja. Sedangkan bagi konsumen, pemenuhan kebutuhan menjadi alasan konsumsi atas produk yang bisa menjadi budaya konsumsi. Pada akhirnya, ketiga pihak ini (produsen-konsumendesainer) harus mampu membangun value culture yakni suatu proses evolusioner dan bukan revolusioner dari sistem produksikonsumsi secara menyeluruh.

Tanpa disadari, mengkonsumsi kemasan adalah sebuah gaya hidup yang sekaligus sebagai representasi akan citra, status sosialkultural hingga ekonomi. Pada akhirnya, desain produk kemasan dan konsumsi 
adalah perpektif yang saling terkombinasi secara baku dan sulit dilepaskan. Meskipun terkadang menjadikan kesadaran palsu (false conscious) bagi penikmatnya tetapi juga menjadi sebuah kebenaran alami yang juga harus diinterpretasikan secara positif pula. Dikarenakan proses konsumsi di sini merupakan instrumen yang cukup signifikan guna menjelaskan gaya hidup masyarakat konsumsi dan desain itu sendiri. Konsumsi desain atau ranah berpikir desain yang dikonsumsikan? Menurut pandangan Irwan Abdullah dapatdidekati dengan tiga cara yakni, pertama, kelas sosial telah membedakan proses konsumsi dimana setiap kelas menunjukkan proses identifikasi yang berbeda. Kedua, barang yang dikonsumsi menjadi wakil kehadiran. Ketiga, berdasarkan proses konsumsi dapat dilihat bahwa konsumsi citra (image) di satu pihak telah menjadi proses konsumsi yang citranya dipancarkan oleh suatu produk dan praktik merupakan ekspresi diri bagi kelompok (Abdullah, 2009: 33-34).

Desain adalah praktek yang tidak terlepas dari benda dan manusia itu sendiri. Sehingga mau tidak mau, sadar tidak sadar, wajib-tidak wajib, harus diperspektifkan secara menyeluruh dan kompleks. Sekali lagi, dalam tulisan ini menunjukkan bahwa desain adalah sebuah pendekatan dengan benda dan manusia sekaligus, sehingga kajiannya memerlukan pendekatan yang lebih holistik dan kompleks termasuk disana aspek kognisi. Karena domain keilmuan desain meliputi aspek kebendaan dan kemanusiaan, fisik-non fisik, konkret-abstak, tubuhpikiran, material-non material, tangibleintangible, yang selalu melibatkan kesadaranketidaksadaran, perasaan, emosi, ide, konsep, intuisi, bahkan yang tak terkatakan (tak terjelaskan)-tacit knowledge yang berbeda dengan keilmuan lain sekaligus merangkul data dari multidipsiplin keilmuan dalam hal ini psikologi. Mengkaji desain kemasan lewat faktor kognisi adalah hal yang belum banyak dilakukan, penelitian ini memang masih perlu waktu untuk menguji sejauh mana aspek kognisi mempengaruhi pemaknaan desain dalam beberapa aspek lain, seperti ekonomi, sosial-budaya, hingga ranah politik sehingga masih diperlukan keberlanjutan penelitian awal ini guna membentuk ranah teoritisasi psikologi desain dengan kajian Budaya-Media sebagai 'pisau bedah'.

\section{DAFTAR PUSTAKA}

Abdullah, Irwan, 2006, Konstruksi dan Reproduksi Kebudayaan, Yogyakarta, Pustaka Pelajar.

(editor), 2009, Dinamika Masyarakat dan Kebudayaan Kontenporer, Yogyakarta, TICI Publications.

Androe, Soedibyo, Cultural Studies: Kaum Muda, Gaya Hidup dan Penolakan, Penerbit Koekoesan, Depok.

Basnendar H, Peranan Desain Kemasan (Packaging) dalam Industri Kreatif, Berbasis Tradisi dalam Menghadapi Era Globalisasi, Procedding Seminar Internasional Industri Kreatif Berbasis Tradisi dalam Era Globalisasi, ISI Surakarta, 17 Desember 2008.

Barker, Chris, 2003, Cultural Studies: Theory and Practice, $2^{\text {nd }}$ editiob, London, SAGE Publications.

Barker, Chris, 2009, Cultural Studies: Teori dan Praktek, Terjemahan Edisi Kelima, Yogyakarta, Kreasi Wacana.

Barthes, Roland, 2007, Membedah Mitos-mitos Budaya Massa: Semiotika atau Sosiolog Tanda, dan Representasi, Yogyakarta, Jalasutra..

Bernhard E. Burdel, 2005, Design: History, Theory and Practice of Product Design, Birkhauser, Basel.

Boudrillard, Jean P. 2009, Masyarakat Konsumsi, Yohyakarta, Kreasi Wacana, Edisi Ketiga.

Christine Suharto Cenadi, Peranan Desain Kemasan dalam Dunia Pemasaran, Jurnal Nirmana Vol. 2 - No. 1, Januari 2000, Universitas Kristen Petra Surabaya.

Departemen Perdagangan Republik Indonesia, Pengembangan Ekonomi KreatifIndonesia 
2025, Studi Industri Kreatif IndonesiaDeperindag RI, 2008.

Horst Oehlke, 2009, Mencari Semiotika Objek Desain dalam Semiotika Visual dan Semantika Produk, Editor Susann Vihma \& Seppo Vakeva, Yogyakarta, Jalasutra.

Iwan Wirya, 1999, Kemasan yang Menjual, Jakarta, PT. Gramedia Pustaka Utama.

Jones, J. Christopher, 1970, Design Methods, London, Wiley Interscience.

Jefkins, Frank, 1985, Periklanan, Penerjemah Haris Munandar, Jakarta, Erlangga.

Junaidi Hidayat, Moch, 2009, Desain Kemasan Untuk UKM, Materi Pelatihan Pengembangan Klinik Kemasan Produk UKM Jawa Timur, Dinas Perindustrian dan Perdagangan Jatim-LPPM ITATS.

Julier, Guy, 2008, The Cultue of Design, Sage, London.

Julier, Guy, Design Issues: Volume 22, No 1 tahun 2006

Kertajaya, Hermawan, 1996, Marketing Plus 2000 Siasat Memenangkan Persaingan Global, Jakarta, PT. Gramedia Pustaka Utama.

Kertajaya, Hermawan, 2002, On Marketing, Jakarta, PT. Gramedia Pustaka Utama.

Klimchuk, Rosner Marianne, Sandra A. Krasovec, 2007, Desain Kemasan, Perencanaan Merek Produk yang Berhasil Mulai Konsep sampai Penjualan, Jakarta, Erlangga.

Lawson, Bryan, 1980, How Designer Think, London, The Architecture Press Ltd.

Meenakshi Gigi Durham, Dauglas M. Kellner, 2006, Media and Cultural Studies-Keywork, Hongkong, Blacwell Publishing.

Norman, Donald A. 2004, Emotional Design: Why We Love (or Hate) Everyday Things, Basic Book, New York.

Piliang, Yasraf Amir, 2004, Posrealitas: Realitas Kebudayaan dalam Era Postmetafisika,
Yogyakarta, Jalasutra.

Piliang, Yasraf Amir, 2008, Multiplisitas dan Deferensiasi-Redifinisi Desain, Teknologi, dan Humanitas, Jalasutra, Yogyakarta.

Richard Harker, Cheele Mahar, 2009, (Habitus $x$ Modal $)+$ Ranah $=$ Praktek, Yogyakarat, Jalasutra.

Robert Wuthnow, James D Hunter, Albert Bergesen, 1984, Cultural Analysis, Boston, Routledge \& Kegan Paul.

Sabana, Setiawan, 2001, Kemasan Tradisional Makanan Khas Sunda - Ungkapan Simbolikdan Estetik SeniRupa Tradisional Sunda, Bandung Penerbit ITB.

Slack, Lauara,2006, What is Product Design, Singapura, Page One.

Stenberg, Robert J, 2008, Psikologi Kognitif, Yogyakarta, Pustaka Pelajar.

Storey, John, 2007, Cultural Studies dan Kajian Budaya Pop, Yogyakarta, Jalasutra.

Sparke, BA, PhD, Penny, 1986, Design and Culture, London, Allen \& Unwin.

Sutrisno, Mudji, 2009, Cultural Studies-Tantangan Bagi Teori-teori Besar Kebudayaan, Depok, Penerbit Koekoesan.

Walker, John A, 1989, Design History and the History of Design, Pluto Press, London

Walker, John A, 2010, Desain, Sejarah, Budaya - Sebuah Pengantar Komprehensif, Yogyakarta, Jalasutra.

Wiyancoko, Dudy, 2007, Desain Kemasan Menentukan Nilai Produk, Makalah Klinik Kemasan, Departemen Perdagangan Republik Indonesia.

\section{Majalah dan Web:}

Gong, Majalah Seni Budaya, Edisi 108/X/2009

http: / / fordiletante.wordpress. com/2008/04/15/kebudayaanpostmodern-menurut-jeanbaudrillard/ diunduh pada Senin, 4 Januari 2010 pukul 23.45 Wib. 